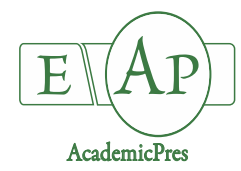

Popescu R and Sofletea N (2020)
Notulae Botanicae Horti Agrobotanici Cluj-Napoca 48(2):1057-1069
DOI: $10.15835 /$ nbha48211897
Research Article

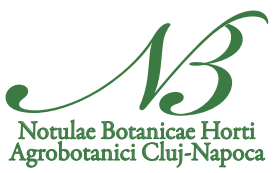

\title{
Spring and autumn phenology in sub-mesothermal beech stands from the southwestern extremity of the Carpathians
}

\author{
Radu POPESCU*, Neculae ȘOFLETEA \\ Transilvania University of Braşov, Faculty of Silviculture and Forest Engineering, Sirul Beethoven 1, Brașov, \\ România; popescu.radu@unitbv.ro (*correspondingauthor);nic.sofletea@unitbv.ro
}

\begin{abstract}
The research carried out was aimed at assessing the phenological behavior of beech (Fagus sylvatica L.) in the southwestern area of the Carpathians, in sub-mesothermal forest sites, which are different from the majority mesothermal ones of this species. The data obtained can be used for predicting the phenological changes of the species, especially in the Carpathian area, under the future influence of expected climate change. Assessments for spring and autumn phenology (buds burst-BB and foliation, flowering and leaves senescence) were carried out in 3 phenological research areas located at $200 \mathrm{~m}, 700 \mathrm{~m}$ and $1200 \mathrm{~m}$. At each altitude level, 100 trees of I and II Kraft classes were phenologically characterized: 50 trees on the south-facing slope (sunny exposure) and 50 on the north-facing slope (shade exposure). The phenological data were interpreted in relation to climate data (average temperature) recorded in each area by a HOBO U23 Pro v2 sensor. The site conditions of sub-mesothermal climate in the low altitude area led to DOY (day of the year) for BB (buds burst) values below 100. The phenological differentiation of populations is evident in relation to the altitude, while the influence of the exposure is much lower. The gradient values based on altitude sectors highlighted the nonlinearity of the development of foliation phenophase: 1.6 days $/ 100 \mathrm{~m}$ at low altitude, where the beech is under the impact of the sub-mesothermal climate and 4.4 days $/ 100 \mathrm{~m}$ between 700 and $1200 \mathrm{~m}$ altitude. Thus, it has been proven that the foliation onset depends on the cumulation of temperatures in relation to the DOY moment and on the values recorded throughout the vegetative rest. The altitudinal gradient values which are influencing the flowering also differentiate the stands. The leaves senescence has a delay of 1.8 up to 2.4 days per 100 meters altitude, and the length of the vegetation season is reduced more sharply in the upper half of the analyzed altitudinal transect. Our data may be used for predicting the phenological changes, especially in the Carpathian area, under the expected climate change.
\end{abstract}

Keywords: beech; buds burst; flowering; leaves senescence; phenology

\section{Introduction}

Beech (Fagus sylvatica L.) is one of the most important species from forests in Central and Western Europe (von Wuehlisch, 2008). Its eastern and southeastern boundaries of natural distribution are the populations of the Carpathians and the Balkan Mountains. 
Currently, the surface of the beech forests from the Carpathians is expanding. Hence, in the Romanian Carpathians the beech has a share of $29 \%$ of the forested area and about $37 \%$ of the standing volume (about 880 million $\mathrm{m} 3$ ).

Under the impact of present and future climate changes, meaning the probable increase of the incidence of extreme weather events, the beech like other species will face unforeseen situations. So, we should ask ourselves whether it will be able to meet these challenges. Lately, a whole series of works are looking at scenarios in which species, stands and entire ecosystems will be tested (Hamrick, 2004; Keenan, 2015; Thompson et al., 2009). It is assessed that, under the climatic conditions envisaged in the future, the competitive capacity of beech could diminish (Geßler et al., 2007). This requires the forecasting of the impact of these changes and the adaptation of beech forests management, in order to limit the risks to which the species will be subjected in the future (Barna and Scieber, 2011). Of course, the impact of these climate changes is expected to happen, perhaps even with an increased intensity in the marginal areas, as are, for example, the stands investigated in the present paper.

If we want the forest management to be able to find and provide all the answers and solutions to future problems, it must first demonstrate flexibility and ability to adapt to the problems that will arise. This will only be possible if the mechanisms that control and influence living organisms are known. The promotion of provenances with increased adaptability and flexibility, or the proper application of stands conducting management will have no purpose without the objectification of the species response capacity to these changes in their living environment.

Phenology, defined as "the synchronization of the seasonal activities of plants and animals" (Walther $e t$ al., 2002), can provide some answers and solutions for the forestry of the future, as phenophases directly influence phenomena at tree level (crown status, biotic and abiotic injuries, litter accumulations, biomass growth and production, etc.), while the climate signal is considered to be one of the main factors controlling tree growth (Schweingruber and Fritz Hans, 1996).

The ecological behavior of beech in relation to the thermal regime is dependent on the latitude and altitude position of the population (Stănescu et al., 1997). Overall, beech is characteristic for temperate forests (Vitasse et al., 2010; Petrițan et al., 2012). It is a mesothermal species (Șofletea and Curtu, 2007), which determines its preponderance in forests from Central and Western Europe (von Wuehlisch, 2008), but it also occupies important areas eastwards to the Carpathians.

Given the importance of beech-occupied ecosystems, the phenological research on this species has increased in recent years (Čufar et al., 2008; Vitasse et al., 2010; Michelot et al., 2012; Robson et al., 2013; Gressler et al., 2015). However, in the area covered by this research no such study has been done before.

In this context, the present paper aims to make a gradient phenological analysis of beech in an area located at the southwestern extremity of the Carpathian Mountains, in the Poiana Ruscă Mountains (subbranch of the Western Carpathians). The reason why the study was conducted in this area is the existence of particular climatic conditions for beech, since local populations are under the influence of the subMediterranean climate. So that, in stands at low and medium altitudes, the average annual temperature is between 8.5 and $10{ }^{\circ} \mathrm{C}$. In this context, the data obtained will be useful for predicting beech phenology under the possible incidence of future thermal changes, including climate warming. The phenological assessments carried out aimed at: i) highlighting the moment of buds burst and leaf formation; ii) establishing the dynamics of the foliation process; iii) analysis of autumn phenology (specific leaf coloring) and circumscription of the length of the vegetation season; iv) evaluation of the phenology of the flowering process.

The phenological events stated will be analyzed in relation to the temperatures which condition and influence them, along a transect of about $1000 \mathrm{~m}$ difference in level, in three populations separated by a level difference of $500 \mathrm{~m}$. In fact, the phenological study carried out in the sampled sub-mesothermal populations can provide new data on the species' phenology, by comparison with the data published so far predominantly for mesothermic beech populations. 


\section{Materials and Methods}

\section{Description of the study site}

The research was carried out along a transect in the Poiana Ruscă Mountains (Table 1). The massif represents a mountain group belonging to the Western Carpathians of Romania, making the transition between their northern area, the Apuseni Mountains, and the southern major group, the Banat Mountains (Figure 1). They stretch over an area of about $2,640 \mathrm{~km}^{2}$, with average altitudes around $700-1,000 \mathrm{~m}$, the highest altitude being reached at the summit of Padeş, 1,382 m (Pop, 2006). In addition to the general geographical position (close to the eastern boundary of the general beech area), another reason to choose this area for the research was the vertical deviation of over $1,000 \mathrm{~m}$ of beech stands ( $180 \mathrm{~m}$ in Colţul Pietrei area, respectively $1,250 \mathrm{~m}$ in Prisloape area, at the maximum altitude of the species in the study area).

Table 1. Location of phenological research areas

\begin{tabular}{|c|c|c|c|c|c|c|c|}
\hline Phenological area & Exposition & Lat. & Long. & $\begin{array}{c}\text { Altitude } \\
\text { (m) }\end{array}$ & $\begin{array}{l}\text { A.a.t. } \\
\left({ }^{\circ} \mathrm{C}\right)\end{array}$ & $\begin{array}{l}\text { A.a.r. } \\
(\mathrm{mm})\end{array}$ & I.a \\
\hline \multirow{2}{*}{ Colțul Pietrei } & $\mathrm{N}$ & $45^{\circ} 55^{\prime} 25.19^{\prime \prime}$ & $22^{\circ} 40^{\prime} 51.51^{\prime \prime}$ & 200 & \multirow{2}{*}{9.9} & \multirow{2}{*}{775} & \multirow{2}{*}{38.9} \\
\hline & $S$ & $45^{\circ} 55^{\prime} 23.90^{\prime \prime}$ & $22^{\circ} 40^{\prime} 55.08^{\prime \prime}$ & 200 & & & \\
\hline \multirow{2}{*}{ Fața Roșie } & $\mathrm{N}$ & $45^{\circ} 49^{\prime} 17.0^{\prime \prime}$ & $22^{\circ} 36^{\prime} 12.1^{\prime \prime}$ & 700 & \multirow{2}{*}{8.7} & \multirow{2}{*}{578} & \multirow{2}{*}{53.1} \\
\hline & $S$ & $45^{\circ} 49^{\prime} 11.3^{\prime \prime}$ & $22^{\circ} 36^{\prime} 12.8^{\prime \prime}$ & 700 & & & \\
\hline \multirow{2}{*}{ Prisloape } & $\mathrm{N}$ & $45^{\circ} 41^{\prime} 10.8^{\prime \prime}$ & $22^{\circ} 29^{\prime} 25.9^{\prime \prime}$ & 1200 & \multirow{2}{*}{6.7} & \multirow{2}{*}{886} & \multirow{2}{*}{30.9} \\
\hline & $S$ & $45^{\circ} 41^{\prime} 9.1^{\prime \prime}$ & $22^{\circ} 29^{\prime} 23.5^{\prime \prime}$ & 1200 & & & \\
\hline
\end{tabular}

Exp - exhibition; A.a.t - average annual temperature; A.a.r. - average annual rainfall; I.a. -annual aridity index of Martonne
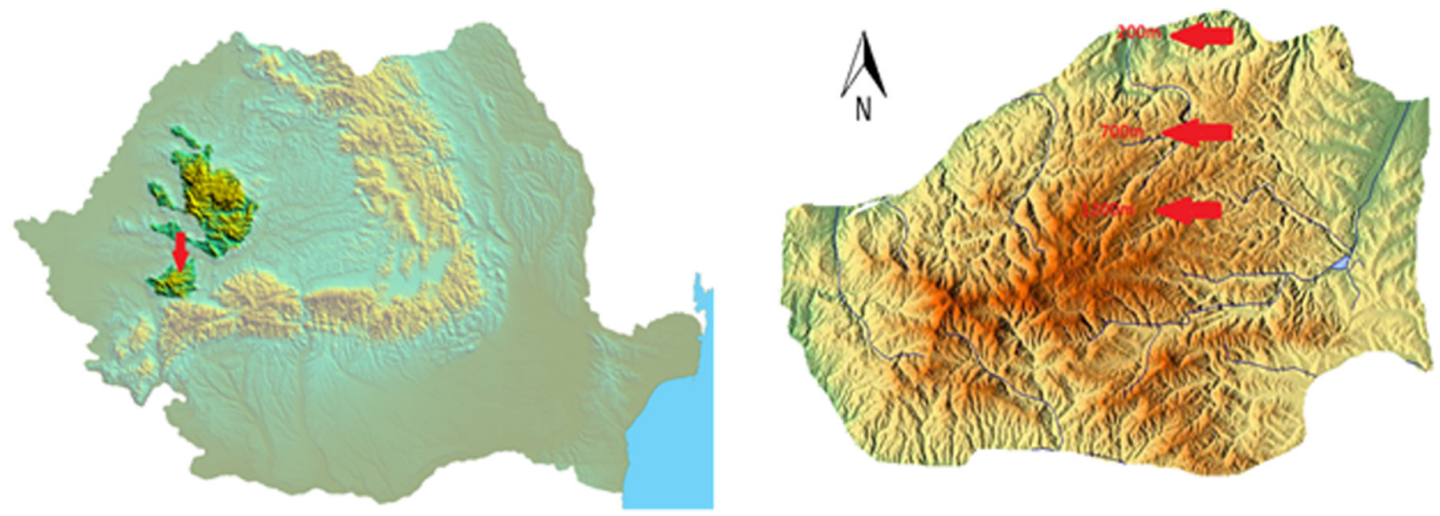

Figure 1. Location of the study area

(A) Poiana Ruscă Mountains, sub-branch of the Western Carpathians (source for the map under license: https://creativecommons.org /licenses/by-sa/3.0/); (B) The transect and location of the three altitudinal levels for phonological research areas (source for the map of the Poiana Ruscă Mountains: https:// upload.wikimedia.org /wikipedia/ro/6/67/Harta_Poiana_Rusca.png)

\section{Protocol for collecting data}

The phenological assessment was carried out on three altitude levels - at 200, 700 and 1,200 m - and it is expected that the information obtained should be useful for objectifying the management of beech stands separated on altitude levels of $500 \mathrm{~m}$. At each altitude level, there were evaluated 100 trees, 50 of them on the south-facing slope (sunny exposure) and 50 on the north-facing slope (shade exposure). Phenological research surfaces include pure or almost pure beech stands with a species participation norm of at least $90 \%$. Only trees of I and II Kraft classes, the main producers of biomass at stands level, were included in the research sample, but also because they are very important for the regeneration process in order to create the future generation. 
In each of the 6 phenological surfaces, it was placed a HOBO U23 Pro v2 sensor, which recorded the relative temperature and humidity during 3 seasons of vegetation for the analysis of autumn phenophases, respectively 2 seasons of vegetation in the case of spring phenophases. The phenological observations were made at the level of each tree by means of a telescope, with the following assessments being carried out:

- Buds opening and foliation. For this phenophase, it was used the following quantification scale: 1unopened buds; 2-the onset of the opening of buds and the appearance of leaves; 3 -completion of the foliation (leaves fully developed throughout the crown).

Depending on the dynamics of the foliation, the trees from each phenological area were classified into one of the following categories: early-flushing trees, intermediate or late-flushing trees.

For tree distribution by phenological categories, it was calculated the average value DOY, for stage 2 of the quantification scale and the standard deviation. Trees deviating from this value with 5 units of standard deviation from average represented the group of early-flushing trees, respectively the late-flushing trees.

- Flowering. For reasons of accuracy, this phenophase was analyzed for male flowers, which were easier to observe and evaluate. Within it, there were divided three stages, namely: 1-absent flowers; 2 -formed but sexually immature flowers; 3 - formed mature flowers in the pollen release stage. The sexual immaturity and maturity were assessed by identifying the moment when flowers became fit for pollen release. Since the flowering phenophase at beech is always preceded by the foliation phenophase, its circumscription and the analysis of the factors that influence it were reported at the time when the leaves reached its maximum size.

- The coloring and fall of leaves. The phenological classification of trees in relation to this phenophase was achieved as follows: 1-absence of specific senescence coloration; 2 - more than $50 \%$ of leaves have specific colorations of entering in the stage of vegetative rest; 3 - over $50 \%$ of the leaves are fallen from the crown.

\section{Results}

\section{Buds burst and foliation}

From the analysis of the onset of the foliation process in relation to altitude, there resulted, as expected, a phenological differentiation of gradientally disposed populations, by the delay of the foliation as the altitude increases (Figure 2). However, the average values - for the 100 trees evaluated at each altitude level- are very close between the first two altitude levels (DOY=98 at an altitude of $200 \mathrm{~m}$ and 106 at an altitude of $700 \mathrm{~m}$ respectively). A 30-day gap is recorded on average between the populations at the extreme points of the transect (i.e. at the altitude limits of beech's area in the study zone). On the north slope, the delay of the phenophase of foliation is no more than 6 days (data not shown).

The individual dynamics of the buds opening and the completion of the formation of leaves is presented in Table 2.

It has emerged that, on average, the process occurs at tree level in an interval of about 6-10 days, but slower in the low-altitude population. The average daily temperatures during the foliation period are around $10^{\circ} \mathrm{C}$ in the researched area, being slightly higher in the low-altitude population $\left(10.8^{\circ} \mathrm{C}\right)$.

Table 3 shows the data for average daily temperatures resulting from sensor recordings during the two years of measurements, depending on the exposure of the population analyzed. In the first situation (Table 3a), there is presented the average daily temperatures summed up in the interval between the fall of the leaves (EVS - end of vegetation season) and the opening of the buds in the spring of the following year (BB - buds burst). Although there is a differentiation due to the altitude (accumulated values increasing towards higher altitude), the difference is however, extremely small between populations from 200 and $700 \mathrm{~m}$ respectively). However, the population at the maximum altitude of the species required an increase of $15.8 \%$ for the average daily temperatures accumulated within the specified time frame, compared to the population at the lowest altitude. On the other hand, looking at the time interval circumscribed by DOY in the current year (Table 3b), a lower value was found in the intermediate altitude population (less than $8.2 \%$ compared to the population 
at $200 \mathrm{~m}$ altitude, respectively $20.5 \%$ for the altitude of $1,200 \mathrm{~m}$ ). The smaller difference between the northfacing slope (shade exposure) and the south-facing slope (sunny exposure) at an altitude of 1,200 $\mathrm{m}$ is explained by the lower slopes at this altitude level.

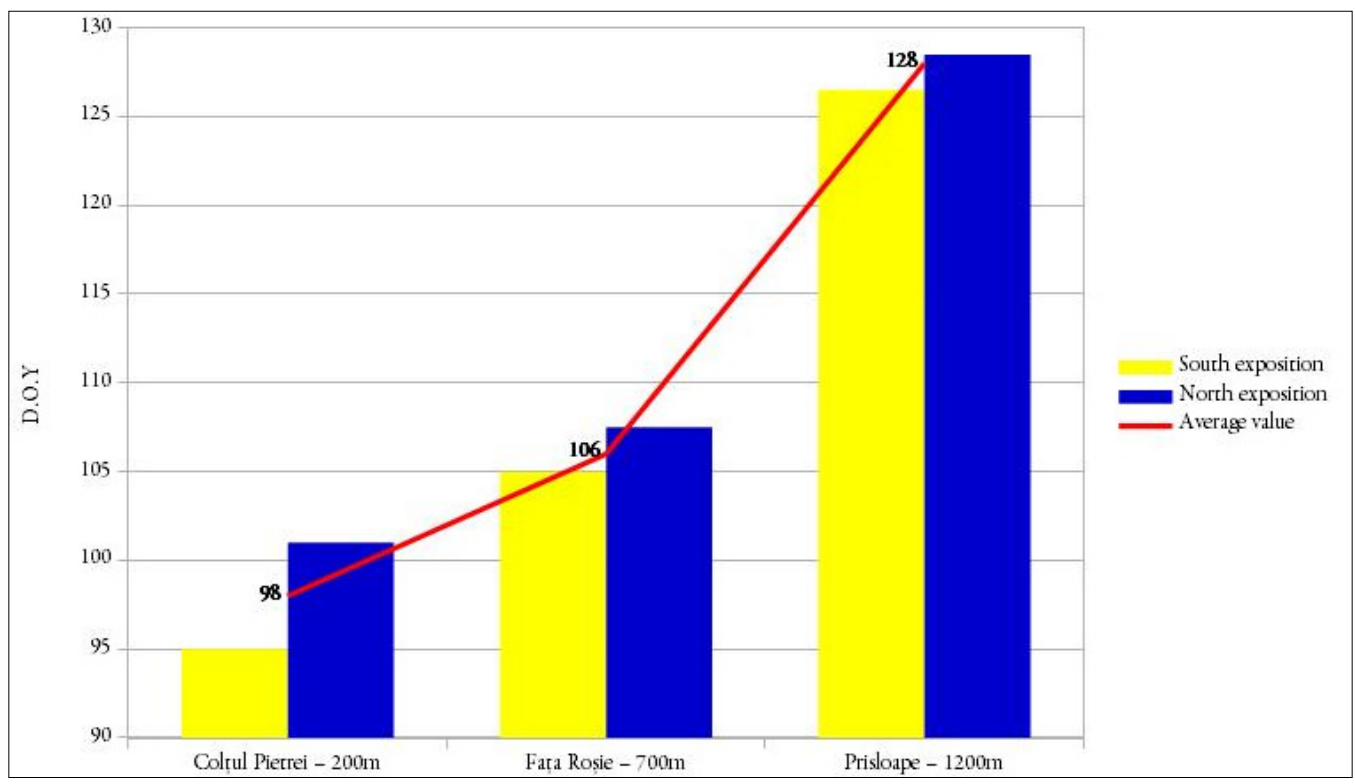

Figure 2. DOY (day of the year) values for foliation relative to the altitudinal position of the population

Table 2. Dynamics of buds opening and leaves formation

\begin{tabular}{|c|c|c|c|}
\hline Phenological area & No of days & Average $\mathrm{T}\left({ }^{\circ} \mathrm{C}\right)$ & $\sum \mathrm{T}\left({ }^{\circ} \mathrm{C}\right)$ \\
Colțul Pietrei $-200 \mathrm{~m}$ & 9.7 & 10.8 & 105.13 \\
\hline Fața Roșie $-700 \mathrm{~m}$ & 6 & 10.3 & 61.75 \\
\hline Prisloape $-1200 \mathrm{~m}$ & 7.2 & 10.4 & 75.61 \\
\hline
\end{tabular}

$\Sigma \mathrm{T}\left({ }^{\circ} \mathrm{C}\right)$ - sum of average daily temperatures

Table 3. Statistical indicators of the sum of average daily temperatures: a) in the range between the entry into vegetative rest in the previous year (EVS) and the buds opening in the current year (BB); $b$ ) in the range circumscribed by DOY in the current year

\begin{tabular}{|c|c|c|c|c|c|}
\hline \multirow{2}{*}{$\begin{array}{c}\text { Phenological } \\
\text { area }\end{array}$} & \multirow{2}{*}{ Altitude $(\mathrm{m})$} & \multicolumn{2}{|c|}{ Sum of average daily temperatures $\left({ }^{\circ} \mathrm{C}\right)$} & \multirow{2}{*}{ Coefficient of variation (\%) } \\
\cline { 3 - 5 } & & \multicolumn{2}{|c|}{ Exposition } & Average & \\
\cline { 2 - 5 } & & South & North & & \\
\hline \multicolumn{7}{|c|}{ a) Values in the range: end of vegetation season (EVS)- buds burst (BB) } \\
\hline Colțul Pietrei & 200 & 417.4 & 472.2 & 444.8 & 34 \\
\hline Fața Roșie & 700 & 417.7 & 479.7 & 448.7 & 7 \\
\hline Prisloape & 1,200 & 496.7 & 533.3 & 515.0 & 19 \\
\hline \multicolumn{7}{|c|}{ b) Values in the range: first day of the year - DOY in which buds burst (BB) take place } \\
\hline Colțul Pietrei & 200 & 245.1 & 294.9 & 270.0 & 10 \\
\hline Fața Roșie & 700 & 226.8 & 268.6 & 247.7 & 8 \\
\hline Prisloape & 1,200 & 356.5 & 359.1 & 357.8 & 19 \\
\hline
\end{tabular}




\section{Autumn phenology and climatic characterization of the vegetation season}

From a phenological point of view, autumn phenophases are particularly important because they mark the end of the vegetation season and the entry of trees into vegetative rest, thus circumscribing the length of the bioactive period. The dating of senescence production was made in relation to the moment when $50 \%$ of the leaves showed the specific coloration of the entry into the vegetative rest. The average data for leaves senescence and the characterization of the vegetation season are presented in Table 4.

Table 4. Average data for leaves senescence and vegetation season

\begin{tabular}{|c|c|c|c|c|c|c|c|}
\hline \multirow{3}{*}{ Phenological area } & \multirow{3}{*}{$\begin{array}{l}\mathrm{DOY}^{a} \\
\text { (days) }\end{array}$} & \multicolumn{2}{|c|}{$\begin{array}{l}\text { Leaves senescence - } \\
\text { yellowing of } 50 \% \text { of the } \\
\text { leaves }\end{array}$} & \multicolumn{3}{|c|}{ Vegetation season } & \multirow{3}{*}{$\begin{array}{l}\text { Coefficient of } \\
\text { variation for } \\
\text { DOY - leaves } \\
\text { senescence }(\%)\end{array}$} \\
\hline & & \multirow{2}{*}{$\begin{array}{l}\text { Average } \\
\text { duration } \\
\text { (days) }\end{array}$} & \multirow{2}{*}{$\begin{array}{l}\text { Average } \\
\text { temperature } \\
\left({ }^{\circ} \mathrm{C}\right)\end{array}$} & \multirow[b]{2}{*}{ No. days ${ }^{b}$} & \multicolumn{2}{|c|}{ Climate conditions } & \\
\hline & & & & & $\begin{array}{l}\mathrm{Tm} \\
\left({ }^{\circ} \mathrm{C}\right)\end{array}$ & $\begin{array}{l}\sum \mathrm{Tm} \\
\left({ }^{\circ} \mathrm{C}\right)\end{array}$ & \\
\hline $\begin{array}{l}\text { Colțul Pietrei - } \\
\quad 200 \mathrm{~m}\end{array}$ & 297 & 14.1 & 9.1 & 199 & 15.7 & $3,124.5$ & 3.5 \\
\hline Fața Roșie - 700 m & 285 & 12.3 & 10.5 & 179 & 14.7 & $2,632.4$ & 2.7 \\
\hline Prisloape - 1,200 m & 276 & 12.4 & 5.9 & 148 & 12.4 & $1,835.2$ & 1.2 \\
\hline
\end{tabular}

a-reported at the beginning of the calendar year;

b-the difference between DOY foliation and DOY leaves senescence;

Tm-average temperature of the vegetation season;

The values calculated for DOY decreased from 297 days in the population from $200 \mathrm{~m}$ altitude to 276 days at an altitude of $1,200 \mathrm{~m}$. On average, DOY value decreased by $4.2 \%$ in the first half of the transect, respectively by $3.3 \%$ in its upper half. On average, about $12-14$ days were needed per altitude level to reach the stage at which $50 \%$ of the leaves turned yellow and the average temperature in that range was about $10{ }^{\circ} \mathrm{C}$ for the first two altitude levels, but with about $4{ }^{\circ} \mathrm{C}$ lower at an altitude of $1,200 \mathrm{~m}$.

In this context, corroborating the data for DOY values at foliation with those for leaves senescence resulted in the decrease on altitude of the length of the vegetation season from 199 days at lower altitude of the transect, to 148 days at the higher altitude. On average, the decrease of the length of the vegetation season is about 4 days $/ 100 \mathrm{~m}$ altitude, but it is substantially increased at the maximum altitude of the species in the studied area. The gradient of the average daily temperature decrease in the vegetation season is double in the upper half of the researched transect $\left(0.46^{\circ} \mathrm{C} / 100 \mathrm{~m}\right)$ compared to the lower half of the transect $\left(0.20^{\circ} \mathrm{C} / 100\right.$ $\mathrm{m})$.

The coefficient of variation shows that the tree stands are very homogeneous from the point of view of leaf fall.

\section{The flowering}

The moment of reference for the flowering phenophase is the end date of the foliation of each tree. As can be seen from Table 5, on average, at the altitude of $200 \mathrm{~m}$ the flowering and maturation of female flowers occurs about 6 days after the average end date of the foliation, respectively at about 8 days at the altitude of $1,200 \mathrm{~m}$. The average temperature in the flowering range is between $9-11^{\circ} \mathrm{C}$, increasing slightly with altitude. On the other hand, the sum of temperatures above $5^{\circ} \mathrm{C}$ in the ND range is about $50 \%$ lower than the higher altitudinal level.

At the same time, at the beginning of the calendar year, for the DOY moment of flowering, there resulted a delay of 1 day $/ 100 \mathrm{~m}$ in the lower half of the transect and 5 days $/ 100 \mathrm{~m}$ at the top of the transect (Figure 3). 
Table 5. Characteristic values of the interval between the complete development of leaves and flowering phenophase

\begin{tabular}{|c|c|c|c|}
\hline Phenological area & $\begin{array}{c}\text { No. days } \\
\left(\mathrm{ND}^{*}\right)\end{array}$ & $\begin{array}{c}\text { Average temperatures of the } \\
\text { flowering interval }\left({ }^{\circ} \mathrm{C}\right)\end{array}$ & $\sum \mathrm{T}>5^{\circ} \mathrm{C}$ \\
\hline Colțul Pietrei - 200 & 5.9 & 9.3 & 55.2 \\
\hline Fața Roșie - 700 & 7.1 & 10.3 & 82.6 \\
\hline Prisloape - 1,200 & 7.9 & 10.8 & 84.8 \\
\hline
\end{tabular}

$\mathrm{ND}^{*}$-number of days between the average leaves production date and the flowering phenophase

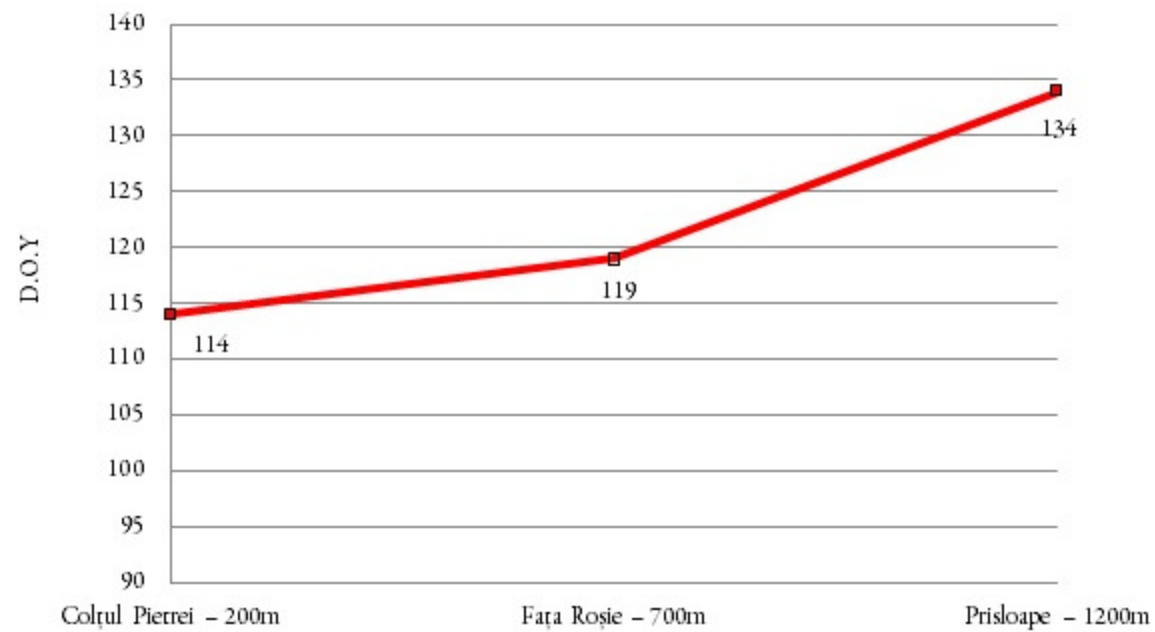

Figure 3. DOY (day of the year) values in which the flowering takes place according to the altitudinal position of the population

\section{Discussion}

In most of the professional works the reference moment for starting of foliation phenophase is often considered in relation to the first day of the year, ignoring the temperatures throughout the vegetative rest period, which are also very important. Moreover, by analyzing the phenology of foliation and flowering in the species Castanea sativa, Teodosiu (2015) observed a strong influence of temperatures in the first three months of winter. For beech and oak, similar conclusions were made in a study for the southern part of France (Dantec et al., 2014). This dependence is also mentioned for beech, in comparative assessments in 1-2-year-old seedlings (Falusi and Calamassi, 1966), or in a trial with provenances originated from 11 countries (Kramer et al., 2017). In fact, the first calendar day of the year is only a conventional benchmark for the calculation of the DOY parameter, while the length of the vegetative rest period and its characteristic thermal values would be expected to have a more objective link to the biological rhythm of succession of the vegetation seasons. Thus, in this paper we analyzed the climatic conditions of the entire rest period.

For the foliation phenophase, the present research quantified the thermal values which influence the study area. It results in a greater need for cumulative average daily temperatures for trees on the shaded slopes compared to the sunny ones. On the other hand, the average gradient value for this climatic parameter in the vegetative rest changes sharply, increasing by altitude from only $0.8^{\circ} \mathrm{C} / 100 \mathrm{~m}$ between the first two altitudinal levels, to $13.3{ }^{\circ} \mathrm{C} / 100 \mathrm{~m}$ between populations located at $700 \mathrm{~m}$ and $1,200 \mathrm{~m}$ respectively. Such a strong influence of the thermal regime during the vegetative rest period at the highest altitude of the species is in accordance with the need of starting late in vegetation, in order to avoid meteorological phenomena that could endanger this process. 
As it is also highlighted in Figure 2, the gradient of BB is not uniform with the altitudinal advance. Up to the altitude of $700 \mathrm{~m}$, where the entry into vegetation of the trees takes place on day 106, this moment is delayed with 1.6 days $/ 100 \mathrm{~m}$ altitude. Between $700 \mathrm{~m}$ and $1,200 \mathrm{~m}$ the gradient increases, thus reaching a delay of the foliation with 4.4 days $/ 100 \mathrm{~m}$ in the upper altitudinal half; this delay in phenophase probably occurs in the species' attempt to avoid late frosts much more frequent at these altitudes.

In the studied area, the foliation gap conditioned by the altitude is different also from the data advanced by Dittmar and Elling (2006) for southern Germany and the value communicated by Cûfar $e t$ al. (2012) for a transect with an altitude difference identical to that in our study where the gradient of late-foliation is of 2 days $/ 100 \mathrm{~m}$ altitude and 2.6 days $/ 100 \mathrm{~m}$ in the second case. Furthermore, we point out the non-linearity of the altitudinal decrease of the gradient showing the start in vegetation, with a higher value between the mountain stands and the premontane ones. This is also important for understanding the implications of flushing on the fitness of altitudinal differentiated populations, as noted in the literature (Robson et al., 2013; Kramer et al., 2017). Our different results are due to the obvious influence of the warmer climate at lower altitudes, an influence that does not exist in the study mentioned above.

Other data similar to ours come from a study conducted on a 16-year-extensive period near Brno (Czech Republic) at an altitude of $625 \mathrm{~m}$ (Bednarova and Melkova, 2007); it resulted that, on average, the opening of $10 \%$ of the buds occurred on the 104th day of the year, approximately the same value as that determined in this study for the starting moment of buds opening at an altitude of $700 \mathrm{~m}$ (a zone of maximum spread of the beech in the analyzed area). The difference between the two cases is recorded in relation to the sum of the average daily temperatures in the period circumscribed by DOY, greater by $16 \%$ in the population evaluated by us in the Poiana Ruscă Mountains. However, it should be considered that, in our case, climate values have been recorded only for several years. Moreover, Bednarova and Melkova (2007) records the great importance of particular climatic conditions from various years on the onset and deployment of spring phenophases, which was also confirmed by Schieber (2006). However, it is surprising in our study that the vegetation season in 2018 was slightly shorter than in other years, although the average temperature in this range was higher at each altitudinal level (Table 4). This could be explained by the fact that, under the impact of this ecological factor, a threshold value has been accumulated which has hastened the senescence of the leaves. Still, this theory should be confirmed by further research directed in this regard because it is possible that the species could suffer the effects of global warming. Anyway, the activation of the foliation phenophase at a certain DOY value is conditioned by a certain value of the cumulative temperatures. In this context, the sum of the cumulative maximum daily temperatures appears to count (Rötzer et al., 2004).

Studies of provenance (Chmura and Rozkowski, 2002; Schueler and Liesebach, 2015) highlighted the delay of the foliation caused not only by climate change on altitude, but also in relation to the latitude of populations. However, the earlier start in vegetation, at all three altitude levels, is quite surprising in our assessments, compared to populations at similar altitudes and average annual temperatures, but in western areas such as those studied in the south of France (Pyrenees) by Dantec et al. (2014). This supports the hypothesis that, however, beech phenology in relation to population latitude does not follow a strict clinal pattern. However, such a model is valid in relation to altitude, but within the same geographical regions, where the thermic regime changes after a certain law.

Regarding the influence of the exposition on the foliation phenology, our study shows an average delay in leaf fall on northern slopes up to 4.8 days than on the southern ones. It should be specified that in stands located at the lower altitudinal limit of beech, this moment can be extended up to 6 days, compared to only 2.6 days in the case of stands located in the middle altitude area. This shows the compression of the phenophases that take place in harsher climatic conditions at high altitudes.

As has emerged in numerous studies on tree phenology, including beech, the most important climatic parameter of influence is the temperature regime. In our study it has resulted that the opening of buds occurs within a time frame when the average daily temperature is about $10{ }^{\circ} \mathrm{C}$, without any marked differences between the three altitudinal levels. However, it is important to note that the differentiation between 
altitudinal levels is evident when we consider the gradient values for the entire vegetation season. Thus, in the stands area of the two halves of the altitudinal transect, there were non-uniformities both for the average temperature (double decrease value of the gradient calculated for the upper altitudinal level) and for the sum of the daily average temperatures (decrease by about $100^{\circ} \mathrm{C} / 100 \mathrm{~m}$ between the altitudinal levels of $200 \mathrm{~m}$ and $700 \mathrm{~m}$, respectively about $155^{\circ} \mathrm{C} / 100 \mathrm{~m}$ between $700 \mathrm{~m}$ and $1,200 \mathrm{~m}$ ). Such climatic differentiations certainly influence and differentiate the bioaccumulation capacity of the species, which is about to be assessed, but which has been already demonstrated in other beech studies (Piovesan et al., 2005; Di Filippo et al., 2007; Jump et al., 2007).

The length of the vegetation season showed no sharp differences for all the samples surveyed on the shaded and sunny exhibition, at the same altitudinal level. This is consistent with the close values recorded on the two exhibitions for the sum of the average daily temperatures of the vegetation season. In contrast, there are big differences between the altitudinal levels, but with sharp decrease in the mountain area. Regarding the senescence of leaves and the length of the vegetation season, in the study carried out by Dittmar and Elling (2007) in southern Germany, similar values to our study were found for the DOY moment of triggering the leaves senescence, but somewhat different for the length of the vegetation season: the values are similar for mountain stands, but higher in our case for premontane ones. In our case, at the altitude of $700 \mathrm{~m}$, higher values for DOY were obtained and compared to similar altitude data from the Czech Republic, near Brno (Bednarova and Melkova, 2007; Bednarova et al., 2010). For the same population in the Czech Republic, Slovikova and Bednarova (2014) highlights a length of the vegetation season between 128 and 181 days, so that the upper extreme is close to the average value identified by us at the altitude of $700 \mathrm{~m}$. We conclude that, in our study, the longer length of the vegetation season is due to the higher average annual temperature of $8.7^{\circ} \mathrm{C}$, compared to only $6.6^{\circ} \mathrm{C}$ in the population of the Czech Republic.

Schieber et al. (2013) analyzed beech phenology in the central area of the Western Carpathians, in Slovakia, along an altitudinal gradient and determined that the autumn phenology of leaves yellowing manifests with a delay of 1.0-1.78 days $/ 100 \mathrm{~m}$. By comparison, in our research, higher values of 2.0-2.4 days $/ 100 \mathrm{~m}$ were obtained, the higher value being characteristic for sub mountain stands under the influence of sub-mesothermal climate. Essentially, there is a correlation between spring and autumn phenophases. Gömöry and Paule (2011) states that the leaves coloring time, although it appears to be subject to a complicated adjustment process, nevertheless, in duration, has greater stability than the foliation, which is also confirmed by our research, as the coloring of $50 \%$ of the leaves occurred within a range of about 12-14 days. Our evaluations, however, did not analyze the entire range of leaves senescence, which appears to take place over a much longer period, even of 40-50 days (Gömöry and Paule, 2011; Schuster et al., 2014). Multiannual analyses have shown that leaves senescence depends to some extent on temperature variations in August and September (Čufar et al., 2012).

Autumn phenology of beech was also assessed by Gressler et al. (2014) in southern Germany, by comparisons between trees divided into three layers: the upper, middle and lower ceiling. It has emerged that the trees in the top layer trigger autumn phenology later than in the other two layers. The specific coloration of the leaf senescence begins around 18 October, which shows similarity, but only for the altitude of $1,200 \mathrm{~m}$, with the trees of the same layer analyzed by us.

The most important data for the process of regeneration and transmission of genetic information to the next generation come from the flowering phenology. In the case of foliation, the value of DOY changes less between the altitudinal levels of $200 \mathrm{~m}$ and $500 \mathrm{~m}$, but it changes more between $700 \mathrm{~m}$ and 1,200 m. In the case of flowering, it appears to be a slightly reversed trend. Thus, in the lower half of the transect the gap gradient between the complete development of leaves and flowering is 0.23 days $/ 100 \mathrm{~m}$, but in the upper half of the altitudinal transect decreases to 0.16 days $/ 100 \mathrm{~m}$. Overall, by altitudinal sectors the phenological gaps are large enough to generate panmixia only on a relatively narrow altitudinal deviation, even though the flow of genes and genotypes along this continuity area of the species would suggest a trend of uniformity. In fact, as it is known, the period of maximum receptivity of flowers is quite small in local populations. At the same time, it should be noted that flowering occurs when the average temperature of the phenophase interval is about 10 
${ }^{\circ} \mathrm{C}$. On the other hand, the sum of the average daily temperatures above the $5{ }^{\circ} \mathrm{C}$ threshold is higher in the upper half of the transect (about $85^{\circ} \mathrm{C}$ ) compared to the lower half (about $55^{\circ} \mathrm{C}$ ), the difference being determined by the different number of days in which the flowering occurs, characteristics probably under a certain genetic-ecological determinism.

\section{Conclusions}

The sub-mesothermal character of the beech, in the lower half of the altitudinal transect analyzed, differentiates these populations from the majority ones within its natural spreading area and from the Carpathians, where the species is mesothermal. In this context, the results of this research provide phenological data expected to occur in current mesothermal populations, under the impact of ongoing climate change.

The results obtained have led to the conclusion that the opening of buds and foliation present both similarities and differences with other studies, regarding the moment of occurrence. The earlier onset of foliation, even when compared to populations from similar climatic conditions, is a proof of a certain phenological plasticity of beech. Therefore, it supports the idea found in some studies that this extremely important European species will be able to bear relatively well the expected climate change in the medium term. But in the long run?

As regards the flushing moment, at the same altitudinal level, the influence of the slope exhibition is not very strong. Instead, the cumulation of average daily temperatures in the circumscribed range of DOY is more important. At the same time, apart from the cumulation of average daily temperatures in the calendar year, it has emerged that, in the determinism of spring phenophases, the thermal regime throughout the vegetative rest season also play an important role. From this perspective, low- and middle-altitude populations differ from high-altitude ones not only in relation to the sum of average daily temperatures in vegetative rest, but also by their greater variability.

A phenological characteristic of the altitudinal transect analyzed is the non-linearity of the foliation gradient, but also the length of the vegetation season. Besides, the flowering phenophase, assessed in relation to the completion of the foliation, does not occur according to a gradient pattern of strict linearity, but also as a DOY positioning in relation to the beginning of the calendar year. However, variations determined by altitudinal sectors are smaller than in the case of foliation. This is a result of a more strictly defined genetic control by the prolonged action of the stabilizing selection.

The altitudinal gap leads to the reproductive isolation of populations located at a considerable altitude difference, probably greater than $400-500 \mathrm{~m}$, which should be proven by future research. That means, populations at the extreme points of the transect are reproductively isolated. This finding is useful for setting limits for the transfer of forest reproductive materials. Even if the sum of the average daily temperatures above the $5^{\circ} \mathrm{C}$ threshold has been shown to be higher in the upper half of the transect, compared to its lower half, the flowering occurs when the average temperature of the phenophase interval is about $10^{\circ} \mathrm{C}$,

Under the influence of climate changes in the not-too-distant future, the early foliation and the long length of the vegetation season in the sub-mesothermal premontane stands investigated can be taken into account for the forecasting of these phenological parameters in stands there are currently mesothermal.

\section{Acknowledgements}

This research received no specific grant from any funding agency in the public, commercial, or not-forprofit sectors. 


\section{Conflict of Interests}

The authors declare that there are no conflicts of interest related to this article.

\section{References}

Barna M, Schieber B (2011). Climate response to forest management in beech stands. Folia Oecologica 38(1):8-16.

Bednáořvá E, Merklová L (2007). Results of monitoring the vegetative phenological phases of European beech (Fagus sylvatica L.) in 1991-2006. Folia Oecologica 34(2):77-84.

Bednářová E, Kučera J, Merklová L (2014). The onset and duration of vegetative phenological stages in European beech (Fagus sylvatica L.) under changing conditions of the environment. Acta Universitatis Agriculturae et Silviculturae Mendelianae Brunensis 58(4):23-30.

Chmura DJ, Rozkowski R (2002). Variability of beech provenances in spring and autumn phenology. Silvae Genetica 51(2-3):123-127.

Čufar K, Prislan P, De Luis M, Gričar J (2008). Tree-ring variation, wood formation and phenology of beech (Fagus sylvatica) from a representative site in Slovenia, SE Central Europe. Trees 22(6):749-758. bttps://doi.org/10.1007/s00468-008-0235-6

Čufar K, De Luis M, Saz MA, Črepinšek Z, Kajfež-Bogataj L (2012). Temporal shifts in leaf phenology of beech (Fagus sylvatica) depend on elevation. Trees 26(4):1091-1100. https://doiorg/10.1007/s00468-012-0686-7

Dantec CF, Vitasse Y, Bonhomme M, Louvet JM, Kremer A, Delzon S (2014). Chilling and heat requirements for leaf unfolding in European beech and sessile oak populations at the southern limit of their distribution range. International Journal of Biometeorology 58(9):1853-1864. https://doi.org/10.1007/s00484-014-0787-7

Di Filippo A, Biondi F, Čufar K, De Luis M, Grabner M, Maugeri M, ... Piovesan G (2007). Bioclimatology of beech (Fagus sylvatica L.) in the Eastern Alps: spatial and altitudinal climatic signals identified through a tree- ring network. Journal of Biogeography 34(11):1873-1892. https://doi.org/10.1111/j.1365-2699.2007.01747.x

Dittmar C, Elling W (2006). Phenological phases of common beech (Fagus sylvatica L.) and their dependence on region and altitude in Southern Germany. European Journal of Forest Research 125(2):181-188. https://doi.org/10.1007/s10342-005-0099-x

Dittmar C, Elling W (2007). Dendroecological investigation of the vitality of common beech (Fagus sylvatica L.) in mixed mountain forests of the Northern Alps (South Bavaria). Dendrochronologia 25(1):37-56. https://doi.org/10.1016/j.dendro.2007.01.003

Falusi M, Calamassi R (1996). Geographic variation and bud dormancy in beech seedlings (Fagus sylvatica L). Annales des Sciences Forestières 53(5):967-979.

Geßler A, Keitel C, Kreuzwieser J, Matyssek R, Seiler W, Rennenberg H (2007). Potential risks for European beech (Fagus sylvatica L.) in a changing climate. Trees 21(1):1-11. https://doi.org/10.1007/s00468-006-0107-x

Gömöry D, Paule L (2011). Trade-off between height growth and spring flushing in common beech (Fagus sylvatica L.). Annals of Forest Science 68(5):975-984. https://doi.org/10.1007/s13595-011-0103-1

Gressler E, Jochner S, Capdevielle-Vargas RM, Morellato LPC, Menzel A (2015). Vertical variation in autumn leaf phenology of Fagus sylvatica L. In southern Germany. Agricultural and Forest Meteorology 201:176-186. https://doi.org/10.1016/j.agrformet.2014.10.013

Hamrick JL (2004). Response of forest trees to global environmental changes. Forest Ecology and Management 197(13):323-335. https://doi.org/10.1016/j.foreco.2004.05.023

Jump AS, Hunt JM, Penuelas J (2007). Climate relationships of growth and establishment across the altitudinal range of Fagus sylvatica in the Montseny Mountains, northeast Spain. Ecoscience 14(4):507-518. https://10.2980/11956860(2007)14[507:CROGAE]2.0.CO;2

Keenan RJ (2015). Climate change impacts and adaptation in forest management: a review. Annals of Forest Science 72(2):145-167. https://doi.org/10.1007/s13595-014-0446-5

Kramer K, Ducousso A, Gömöry D, Hansen J K, Ionita L, Liesebach M, ... Von Wühlisch G (2017). Chilling and forcing requirements for foliage bud burst of European beech (Fagus sylvatica L.) differ between provenances and are 
Popescu R and Sofletea N (2020). Not Bot Horti Agrobo 48(2):1057-1069

phenotypically plastic. Agricultural and Forest Meteorology 234:172-181. https://doi.org/10.1016/j.agrformet.2016.12.002

Michelot A, Simard S, Rathgeber C, Dufręne E, Damesin C (2012). Comparing the intra-annual wood formation of three European species (Fagus sylvatica, Quercus petraea and Pinus sylvestris) as related to leaf phenology and nonstructural carbohydrate dynamics. Tree Physiology 32(8):1033-1045. https://doi.org/10.1093/treephys/tps052

Petrițan AM, Biriș IA, Merce O, Turcu DO, Petrițan IC (2012). Structure and diversity of a natural temperate sessile oak (Quercus petraea L.) European Beech (Fagus sylvatica L.) forest. Forest Ecology and Management 280:140-149. https://doi.org/10.1016/j.foreco.2012.06.007

Piovesan G, Biondi F, Bernabei M, Di Filippo A, Schirone B (2005). Spatial and altitudinal bioclimatic zones of the Italian peninsula identified from a beech (Fagus sylvatica L.) tree-ring network. Acta Oecologica 27(3):197-210. https://doi.org/10.1016/j.actao.2005.01.001

Pop G (2006). Carpații şi Subcarpații României [Carpathians and sub-Carpathians of Romania]. Cluj University Press, Cluj-Napoca, Romania.

Robson TM, Rasztovits E, Aphalo PJ, Alia R, Aranda I (2013). Flushing phenology and fitness of European beech (Fagus sylvatica L.) provenances from a trial in La Rioja, Spain, segregate according to their climate of origin. Agricultural and Forest Meteorology 180:76-85. https://doi.org/10.1016/j.agrformet.2013.05.008

Rötzer T, Grote R, Pretzsch H (2004). The timing of bud burst and its effect on tree growth. International Journal of Biometeorology 48(3):109-118. https://doi.org/10.1007/s00484-003-0191-1

Schieber B (2006). Spring phenology of European beech (Fagus sylvatica L.) in a submountain beech stand with different stocking in 1995-2004. Journal of Forest Science 52(5):208-216.

Schieber B, Janík R, Snopková Z (2013). Phenology of common beech (Fagus sylvatica L.) along the altitudinal gradient in Slovakia (Inner Western Carpathians). Journal of Forest Science 59(4):176-184. https://doi.org/10.17221/82/2012-JFS

Schueler S, Liesebach M (2015). Latitudinal population transfer reduces temperature sum requirements for bud burst of European beech. Plant Ecology 216(1):111-122. https://doi.org/10.1007/s11258-014-0420-1

Schuster C, Kirchner M, Jakobi G, Menzel A (2014). Frequency of inversions affects senescence phenology of Acer pseudoplatanus and Fagus sylvatica. International Journal of Biometeorology 58(4):485-498. https://doi.org/10.1007/s00484-013-0709-0

Schweingruber FH (1996). Tree rings and environment. Dendroecology. Paul Haupt, Bern, Swiss

Slovíková K, Bednářová E (2014). Monitoring of vegetative phenological stages in European beech (Fagus sylvatica L.) growing in a mixed stand. Acta Universitatis Agriculturae et Silviculturae Mendelianae Brunensis 62(5):11091115. https://doi.org/10.11118/actaun201462051109

Stănescu V, Șofletea N, Popescu O (1997). Flora forestieră lemnoasă a României [Woody Flora of Romania]. Ed. Ceres, Romania.

Șofletea N, Curtu AL (2007). Dendrology. Transilvania University Press, Brasov, Romania.

Teodosiu M (2015). Determinismul climatic al producerii fenofazelor la specii forestiere cu serii maximale din România [Climatic determinism of the production of phenophases in forest species with maximum series in Romania] Bucovina Forestieră 15(1):31-44.

Thompson I, Mackey B, McNulty S, Mosseler A (2009). Forest resilience, biodiversity, and climate change. In Secretariat of the Convention on Biological Diversity, Montreal. Technical Series 43:1-67.

von Wuehlisch G (2008). EUFORGEN Technical Guidelines for genetic conservation and use for European beech (Fagus sylvatica). Biodiversity International, Rome, Italy pp 6.

Vitasse Y, Bresson CC, Kremer A, Michalet R, Delzon S (2010). Quantifying phenological plasticity to temperature in two temperate tree species. Functional Ecology 24(6):1211-1218. https://doi.org/10.1111/j.13652435.2010.01748.x

Walthers GR, Post E, Convey P, Menzel A, Parmesan C, Beebee TJ, ... Bairlein F (2002). Ecological responses to recent climate change. Nature 416:389-395. 
Popescu R and Sofletea N (2020). Not Bot Horti Agrobo 48(2):1057-1069

OPEN ACCESS The journal offers free, immediate, and unrestricted access to peer-reviewed research and scholarly work. Users are allowed to read, download, copy, distribute, print, search, or link to the full texts of the articles, or use them for any other lawful purpose, without asking prior permission from the publisher or the author.

(c) (i)

License - Articles published in Notulae Botanicae Horti Agrobotanici Cluj-Napoca are Open-Access, distributed under the terms and conditions of the Creative Commons Attribution (CC BY 4.0) License.

(c) Articles by the authors; UASVM, Cluj-Napoca, Romania. The journal allows the author(s) to hold the copyright/to retain publishing rights without restriction. 